\section{Editorial Division}

Chairman Editorial Board

Prof. Abdul Mannan Miah

Executive Editor

Prof. M.A. Faiz

Managing Editor

Dr. Md. Abdus Salam

Assistant Editors

Prof. F. M. Siddiqui

Prof. Syed Azizul Haque

Dr. Firoz Quader

Dr. S.M. Rafiqul Islam Bacchu

\section{Members}

Prof. Abul Qasem

Prof. Abu Ahmed Chowdhury

Prof. M. A. Majed

Prof. A.K. Shamsuddin Siddiqui

Prof. A. Bayes Bhuiyan

Prof. M. Nabi Alam Khan

Prof. M. A. Majid

Prof. Maidul Islam

Prof. Md. Tahir

Prof. Atai Rabbi

Prof. Hasina Banoo

Prof. Ata Alahi Khan

Prof. K.M.H.S. Sirajul Haque

Prof. Anwara Begum

Prof. Mahmudur Rahman

Prof. A.K.M. Shafiqur Rahman

Prof. S.A.R. Chowdhury

Prof. Shah Md. Keramat All

Prof. Khadeza Begum

Prof. Ruhul Amin Miah

Prof. Mozammel Hoque

Prof. Abid Hossain Mollah

Prof. Ferdous Ara J. Janan

Prof. Harun-ur-Rashid

Prof. M. Abdullah

Prof. Tofayal Ahmed

Prof. Motahar Hossain

Prof. Shayeba Akhter

Prof. Abu Ahmed Ashraf Ali

Prof. Abu Hanif

Prof. Hosne Ara Tahmin

Prof. A.K.M. Azizul Haque

Prof. M. Ruhul Amin

Prof. Abdul Hannan

Prof. Jahangir Kabir

Prof. C. H. Kabir

Prof. Quzi Deen Mohammad

Prof. Sufia Rahman

Prof. M. Selim Shakur

Prof. K.H.M. Firoz

Prof. Saidur Rahman

Prof. Matiur Rahman

Prof. Abidul Haque

Prof. M.M. Shariful Alam

Prof. A.Y.M. Elahi Choudhury

Prof. N.A. Kamrul Ahsan

Prof. Mostaque Rahim Swapon

Prof. Omar Ali

Prof. Shaheen Choudhury

Prof. Mohammad Saiful Islam

Prof. Atiqur Rahman

Prof. Syed Md. Akram Hussain

Dr. Jahangir Kabir

Dr. Jamanul Islam Bhuiyan

Dr. Md. Munir Hossain

\section{The Editorial}

\section{CONDUCTING GLOBAL ADULT TOBACCO SURVEY (GATS) USING DIGITAL TECHNOLOGY IN BANGLADESH}

Tobacco is one of the leading causes of death worldwide. These deaths are preventable. Threequarter of the tobacco users live in 15 countries, Bangladesh being one of them. Bangladesh identified tobacco epidemic as one of its important public health problems. In response, it has enacted the tobacco control law in 2005 and formulated its rules in $2006^{1}$. National Strategic Plan of Action for Tobacco Control, 2007-2010 has been developed and implemented with technical assistance from $\mathrm{WHO}^{2}$. Some visible progresses have been made in tobacco control in Bangladesh in spite of poor enforcement of the law by the authority. However, public in general (and non-smokers in particular) have supported this law and socialized this by means of protests and requests. Public etiquettes have improved regarding smoking in public places and transports.

A recent study conducted by WHO all over the country indicates that 37 percent of people aged 15 years and above use tobacco in any form, smoking or smokeless. In 2004 tobacco use attributed to 57 thousand deaths. Bangladesh incurred a net loss of 2,600 crore Taka in that year $^{3}$. Generation of evidences at regular interval in standardized manner is needed for policies and programmes. Community interventions aided by cessation support has already been proved to be effective in Bangladesh ${ }^{4}$.

For global comparability, data collection using similar approach through out the world is needed. Bloomberg Philanthropies New York, USA came forward to support the tobacco free initiatives taken by $\mathrm{WHO}$ and other organizations. With this financial support CDC Foundation and WHO initiated as survey entitled Global Adult Tobacco Surveys (GATS) to monitor global tobacco use among adults. Bangladesh is a part of this initiative to determine the prevalence of tobacco use among general population aged 15 years and above. The second objective was to strengthen the capacity of national institutes to conduct studies in future. Therefore a huge investment has been done in developing the electronic tools and establishing systems of digital survey. This is a real example of digitalization of Bangladesh in line with current Governments commitment to the people.

Steering and technical committees were formed to guide the study. The implementing agency of this study is the National Institute of Preventive and Social Medicine (NIPSOM). Collaborating organizations are Bangladesh Burea of Statistics (BBS) and National Institute of Populations Research and Training (NIPORT). Investigators were drawn from NIPSOM and Bangabandhu Sheikh Mujib Medical University (BSMMU).

Bangladesh Bureau of Statistics has traditionally been using mouja (in rural) and mahalla (in urban areas) as primary sampling units. Four hundred (200 urban, 200 rural) PSUs are

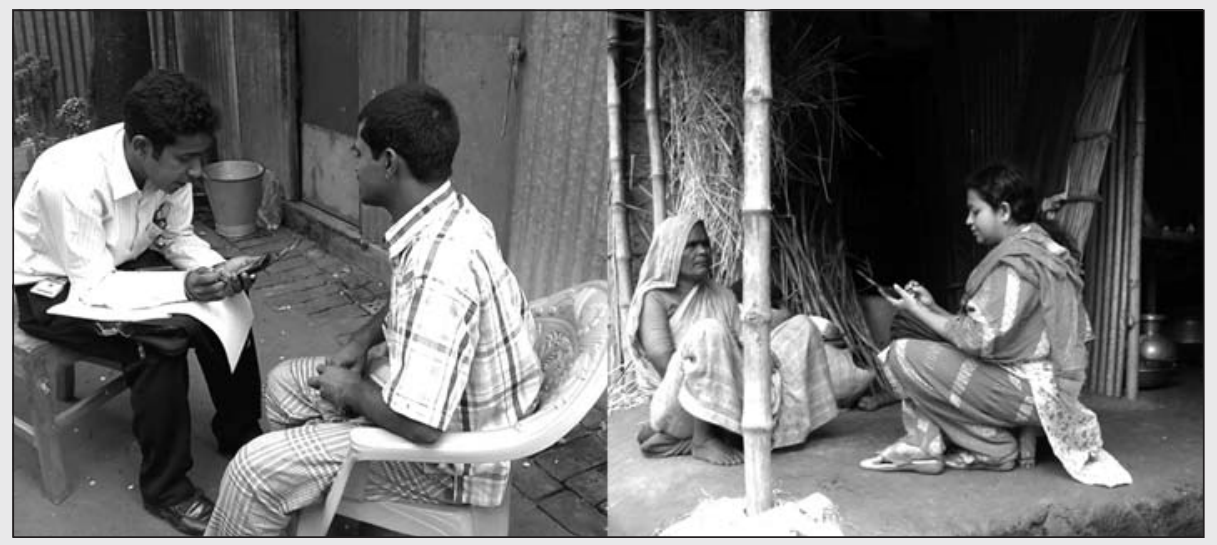




\section{The Editorial}

used for GATS. BBS updated the mapping and listing of these 400 randomly selected Primary Sampling Unit (PSU) throughout the country. Enumerators have collected data using iPAQ (a PDA), then transferred data to their supervisors' laptop computers through $\mathrm{SD}$ card. It is important to note that female enumerators interviewed females and male interviewers interviewed males (see pictures). The supervisors sent the data to central FTP server established in NIPSOM daily by email using EDGE modems. NIPORT has worked as an independent quality control agent. Beside the quality control done by NIPORT, there were regular quality control checks from NIPSOM investigators and WHO technical officers. BBS officials assisted the field force to in resolve any problem related to the mapping and listing. Therefore it was feasible to successfully complete data collection even in remotest part of the country. The detail of the study and its findings will be released in Dec 2009.

This is the first ever countrywide study in public sector using electronic means. Bangladesh has proved its capability to be one of the champions in this field once again. Rigorous training with active participation of CDC Foundation and WHO, monitoring field implementation, involvement of multiple partners and above all commitment of the Ministry of Health and Family Welfare made this challenging task possible.

\section{Dr M Mostafa Zaman}

National Professional Officer (Non-communicable Diseases) World Health Organization, Bangladesh

Email: zamanm@searo.who.int

1. Tobacco Control Law and Rules and Related Government Orders. Ministry of Health and Family Welfare, Government of People's Republic of Bangladesh, 31 May 2008.

2. National Strategic Plan of Action for Tobacco Control, 2007-2010. Ministry of Health and Family Welfare, Government of People's Republic of Bangladesh, November 2007.

3. Zaman MM, Nargis N, Perucic AM, Rahman K (eds). Impact of Tobacco-related Illnesses in Bangladesh. SEARO, WHO New Delhi 2007.

4. Ahmed J, Choudhury SR, Zaman MM, Sharkar MN. Tobacco cessation among rural women by community health workers in Bangladesh. Poster presented in 14th World Conference on Tobacco or Health. Mumbai, India. 8-12 March 2009. 